\title{
The Efficiency of Different Types of Inoculation of Pure Al and AISi2 Alloy
}

Tomasz Wróbel

Silesian University of Technology, Foundry Department, Towarowa 7, 44-100 Gliwice, Poland.

Email: tomasz.wrobel@polsl.pl

In paper problem concerning inoculation of primary structure of aluminum with purity of $\mathbf{9 9 , 5 \%}$ and $\mathbf{9 9 , 8 \%}$ and AISi2 alloy, which is realized mainly by intensification of liquid metal movement in mould is presented. In aim of realization of forced movement during the crystallization of liquid metal was used rotating electromagnetic field produced by the induction coil supplied by current with elevated frequency. The degree of structure refinement was represented by equiaxed crystals zone content on transverse section of ingot and average area of macro-grain in this zone. Effect of structure refinement obtained by influence of electromagnetic field was compared with refinement obtained by use of traditional inoculation, which consists in introducing of additives i.e. titanium, boron, carbon and strontium to metal bath. The results of studies and their analysis show possibility of effective refinement of pure Al and Al-Si alloy primary structure, only with use of rotating electromagnetic field and without necessity of application of inoculants such a $\mathrm{Ti}$, $\mathrm{B}$ and $\mathrm{C}$. This method of inoculation is important, because inoculants decrease the degree of purity and electrical conductivity of pure Al. Moreover inoculants are reason of point cracks formation during rolling of ingots.

Keywords: Aluminum, Al-Si alloy, Primary structure, Inoculation, Electromagnetic field

\section{Acknowledgements}

Project financed from means of National Science Centre

\section{References}

[1] FRAŚ, E. (2003). Crystallization of metals, 470 p. WNT, Warsaw, Poland.

[2] CHALMERS, B. (1963). The structure of ingot. Journal of the Australian Institute of Metals, Vol. 8, No. 6, pp. 255-263.

[3] OHNO, A. (1976). The solidification of metals, 144 p. Chijin Shokan Co. Ltd, Tokyo, Japan.

[4] SZAJNAR, J., WRÓBEL, T. (2008). Inoculation of pure aluminum with an electromagnetic field. Journal of Manufacturing Processes, Vol. 10, No. 2, pp. 74-81.

[5] ADAMCZYK, J. (2004). Engineering of metallic materials, 342 p. Publishers of Silesian University of Technology, Gliwice, Poland.

[6] MICHALCOV, A., VOJTĚCH D. (2012). Structure of rapidly solidified aluminium alloys. Manufacturing Technology. Vol. 12, No. 13, pp. 166-169.

[7] WRÓBEL, T. (2011). Review of inoculation methods of pure aluminium primary structure. Archives of Materials Science and Engineering. Vol. 50, No. 2, pp. 110-119.

[8] HU, B., LI, H. (1998), Grain refinement of DIN226S alloy at lower titanium and boron addition levels. Journal of Materials Processing Technology. Vol. 74, No. 1-3, pp. 56-60.

[9] JANERKA K., BARTOCHA D., JEZIERSKI J., SZAJNAR J. (2010). The effect of the carburiser quality on the cast iron recarburisation process. Foundry Trade Journal International, Vol. 184, No. 3679, pp. 282-286.

[10] GUZOWSKI, M., SIGWORTH, G., SENTNER, D. (1987). The role of boron in the grain refinement of aluminum with titanium. Metallurgical and Materials Transactions A, Vol. 18, No. 5, pp. 603-619.

[11] JANERKA K., JEZIERSKI J., SZAJNAR J. (2012). Quality and properties of the cast iron produced on the steel scrap base. Archives of Materials Science and Engineering, Vol. 53, No. 2, pp. 92-101.

[12] SZAJNAR, J. (2009). The influence of selected physical factors on the crystallization process and casting structure, 191 p. Archives of Foundry Engineering - Monograph, Katowice-Gliwice, Poland.

[13] GRIFFITHS, W., MCCARTNEY, D. (1997). The effect of electromagnetic stirring on macrostructure and macrosegregation in the aluminium alloy 7150. Materials Science and Engineering: A. Vol.222, No.2, pp.140148.

[14] SZAJNAR, J., WRÓBEL, T. (2008). Influence of magnetic field and inoculation on size reduction in pure aluminium structure. International Journal of Materials and Product Technology. Vol. 33, No 3, pp. 322-334. 
[15] GRIFFITHS, W. \& MCCARTNEY, D. (1997). The effect of electromagnetic stirring on macrostructure and macrosegregation in the aluminium alloy 7150. Materials Science and Engineering:A, Vol. 222, No. 2, pp.140148.

[16] DOHERTY, R.; LEE, H., FEEST, E. (1984). Microstructure of stir-cast metals. Materials Science and Engineering, Vol. 65, pp. 181-189.

[17] CAMPANElla, T., CHARBON, C., RAPPAZ, M. (2004). Grain refinement induced by electromagnetic stirring: a dendrite fragmentation criterion. Metallurgical and Materials Transactions A, Vol. 35, No. 10, pp. 3201-3210.

[18] http://www.struers.com/knowledge 